Bolm Inst. oceanogr., S Paulo, 33(1):29-38, 1985

\title{
ESTIMATE OF EXPLOITATION RATES AND POPULATION SIZE OF SKIPJACK TUNA OFF THE SOUTHEASTERN COAST OF BRAZIL
}

\author{
Silvio JABLONSKI ${ }^{1}$ \& Yasunobu MATSUURA ${ }^{2}$
}

1 Superintendência do Desenvolvimento da Pesca (SUDEPE), Coordenadoria Regional do Rio de Janeiro

2 Instituto Oceanográfico da Universidade de São Paulo

\section{Synopsis}

Size compositions and total landings of skipjack tuna caught in the southeastern Brazilian waters by bait-boats are used as the basis of the assessment of the population for 1980-1983 period, employing the length cohort analysis and virtual population analysis. From monthly size frequency data it is suggested that there is constant immigration and emigration of different modal groups in the fishing area with an interval of two to three months. The exploitation rate was very low for length class between 35-45 cm FL, then increased gradually. The weighted mean exploitation rates were 0.060 and 0.448 , respectively for length classes smaller and larger than $55 \mathrm{~cm} F L$. The estimate of the average number of fish attaining a size of $43 \mathrm{~cm} F L$ (recruit) was $11.0 \times 10^{6}$ fish for assumed values of $M=0.7$ and $K=0.307$. Increasing the fishing mortality rate by $30 \%$ and $50 \%$, an estimated increment in yield is $8 \%$ and $12 \%$, respectively. From virtual population analysis, we obtained the biomass estimate of skipjack population older than two years-old to be 70.3 thousand tonnes for assumed value of $M=0.7$ and the estimated MSY was 24.6 thousand tonnes.

Descriptors: Biomass, Recruitment, Exploitation, Stock assessment, Potential yield, Commercial fishing, Continental shelf break, Pole-line fishing, Katsuwonus pelamis, Scombridae, SW Atlantic, Southern coast: Brazil,

Descritores: Biomassa, Recrutamento, Explotação, Estimativa do estoque, Rendimento potencial, Pesca comercial, Borda da plataforma continental, Pesca com linha/isca-viva, Katsuwonus pelamis, Scombridae, Atlantico Sul Ocidental, Costa sul: Brasil, Costa sudeste: Brasil.

\section{Introduction}

A bait-boat fishery for skipjack tuna (Katsuwonus pelamis) in Brazil began in 1979 and now involves several tens of bait-boats adapted from other fishing boats (Matsuura, 1983a). They operate in the open sea along the edge of the continental shelf off southeastern Brazil from Cape São Tomé $\left(22^{\circ} \mathrm{S}\right)$ to the south of Cape Santa Marta Grande $\left(28^{\circ} 30^{\prime} \mathrm{S}\right)$ (Fig. 1).

The number of bait-boats increased rapidly from seven in 1979 to nearly 100 in 1981-82, decreasing to 60 during 1983. The bait-boat catch has increased from 1,850 tonnes ( $t$ ) in 1979 to about $18,000 \mathrm{t}$ in 1982 . The estimated catch in 1983 will be about $15,500 \mathrm{t}$.

* SUDEPE

Praça XV, no. 2 - 39 and.

20.010 - Rio de Janeiro, RJ.

Publ. n. 613 do Inst. oceanogr. da Usp.
Because the bait-boat fishery in Brazil started recently, there is little information on the biology of skipjack tuna in this area. Most of the information available was collected during the International Skipjack Year Program organized by the International Commission for the Conservation of At lantic Tunas (ICCAT). For example, Cayre \& Farrugio (1983), Goldberg \& Au (1983) and Jablonski et al. (1983) studied the sexual maturity and spawning of skipjack tuna off the southeastern Brazilian coast. Matsuura (1982; 1983b) studied skipjack larval abundance in the western central Atlantic. An analysis of skipjack tuna stomach contents was carried out by Ankenbrandt (1983) and those of predator fish preying on skipjack was made by ZavalaCamin (1982; 1983).

With regard to population dynamics, Fonteneau (1983) used cohort analysis to 


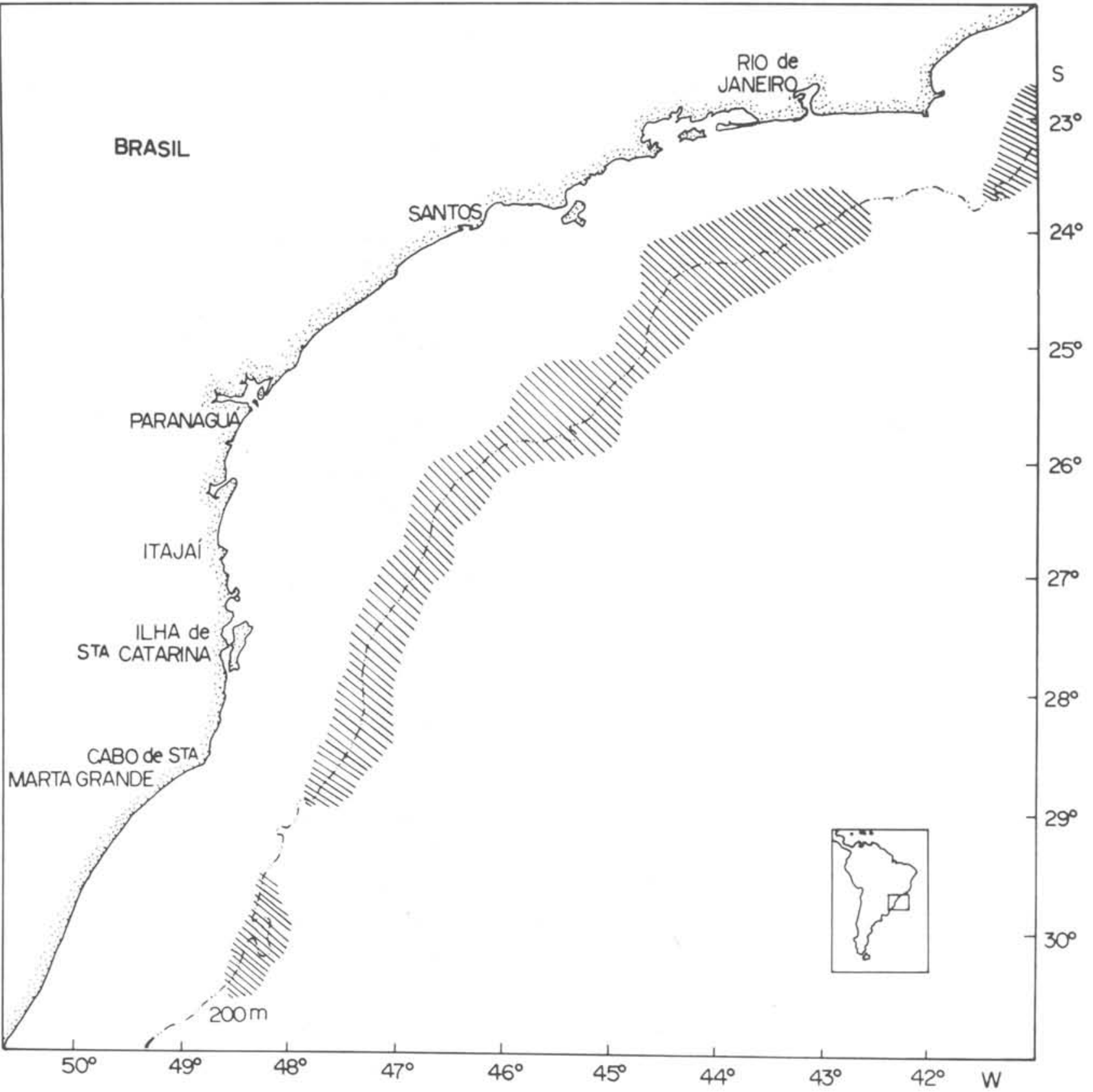

Fig. 1. Main fishing areas of the pole-and-line skipjack fishery in southeastern Brazilian waters.

study the state of Atlantic skipjack stocks, using data taken from both the eastern and western Atlantic. For the eastern Atlantic population he calculated the vectors of the coefficient of fishing mortality (F) using two hypotheses of constant recruitment, i.e. moderate and low exploitation levels.

For the western Atlantic population the same author combined data from the Brazilian bait-boat fishery in 19801981 with those taken from the Caribbean Sea by the United States and Cuban boats since 1973. Neither biomass nor fishery potencial estimates were made for the western Atlantic population.

The present paper estimates annual recruitment and total biomass of the exploited stock of skipjack tuna in the actual fishing area of the Brazilian bait-boats.

\section{Material and methods}

The basic data used were length frequencies obtained from commercial landings at the Rio de Janeiro fish market during the period March 1980 to 
August 1983. Figure 2 shows monthly catches of skipjack tuna from 1979 to 1983 inclusive. The total number of skipjack tunas measured was 27,650 . To cover all the fishing areas, an attempt was made to obtain the maximum number of samples from commercial boats each month. The total catch of skipjack tuna was obtained from the landing control system of the SUDEPE (Superintendência do Desenvolvimento da Pesca), including both the Rio de Janeiro and Itajaí fish markets.

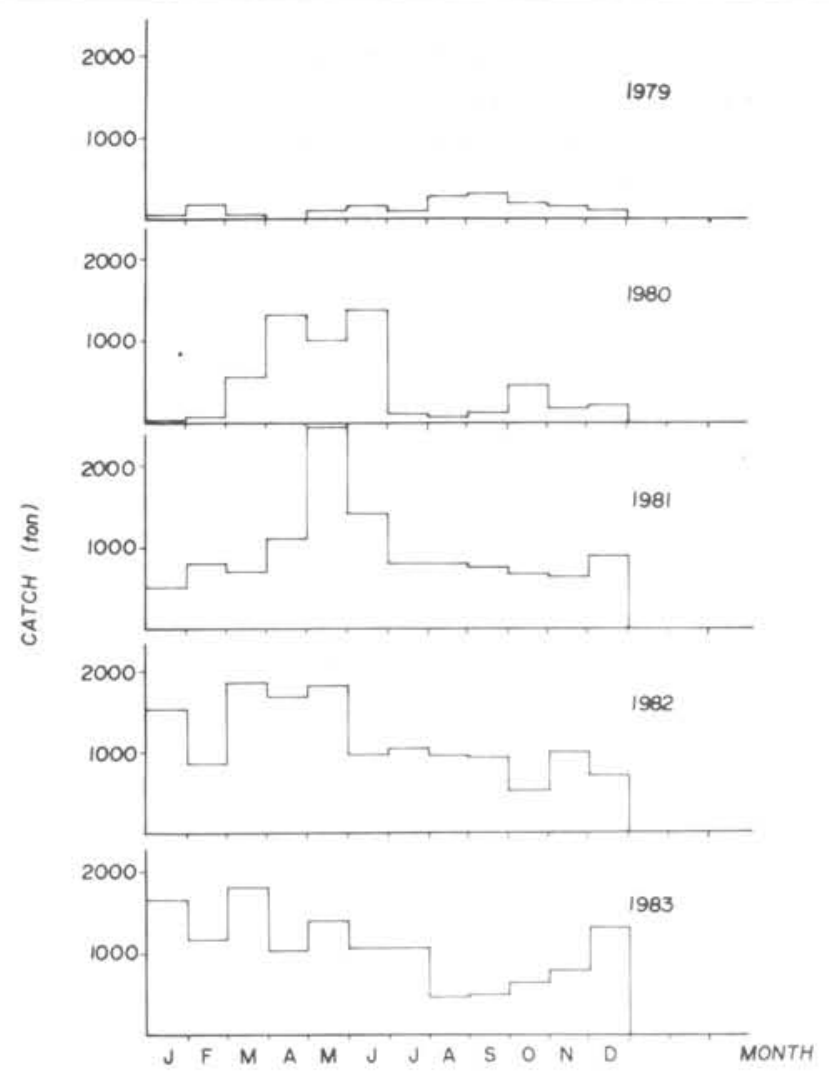

Fig. 2. Monthly catch of the skipjack tuna landed at the fish markets in Rio de Janeiro and I tajai ports, 1979-1983.

The lenght cohort analysis of Jones (1974; 1981) and the virtual population analysis of Gulland (1965) were used to estimate recruitment and population biomass. To estimate potencial yield, the XMB-model of Gulland was used. The maximum sustainable yield (MSY) of fish stock can be estimated with the following formula, MSY $=$ X.M. $B_{\infty}$, where $\mathrm{M}=$ natural mortality coefficient, $\mathrm{B}_{\infty}=$ biomass of virgin stock, and $\mathrm{X}=$ constant. In this paper, the constant $\mathrm{X}=0.5$ was applied.

Population parameters of skipjack tuna were taken from other papers presented in the proceedings of the Internacional Skipjack Year Program. The following parameters were used:

1) Natural mortality coefficient: $M=0.6-0.8 \ldots \ldots$ Fonteneau

2) Length-weight relationship:

$\mathrm{W}=7.48 \times 10^{-6} \times \mathrm{L}^{3.2526}$ ........ Cayre \& Laloe (1983), where $\mathrm{W}=$ weight in $\mathrm{kg}$ and $\mathrm{L}=$ fork length in $\mathrm{cm}$.

3) Von Bertalanffy growth curve constants :

$$
\begin{aligned}
& L_{t}=L_{\infty}\left(1-\operatorname{EXP}\left(-K\left(t-t_{0}\right)\right)\right) \text {, } \\
& \mathrm{L}_{\infty}=86.7 \mathrm{~cm}, \mathrm{~K}=0.307
\end{aligned}
$$

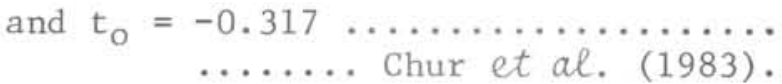

For comparative purpose, another value of $\mathrm{K}$ obtained from tagging data was used:

$K=0.322 \ldots \ldots$ Bard \& Antoine (1983).

The method used to estimate numbers of skipjack tuna caught in each length class was similar to that described by Jones (1979) and to estimate the mean weight at each length class, the equation presented by Cayre \& Laloe (1983) was used.

Using the length frequency data taken at the Rio de Janeiro fish market and catch data from all fishing areas, estimates of the numbers landed in each length class have been made for each year and then the average number of fish for the four year period was calculated (Table 1). Length frequency data from 10 and 8 month periods were used for 1980 and 1983, respectively.

A cohort analysis of the length composition data has been carried out using the method described by Jones (1974; 1981). Because we have a probable range of natural mortality coefficients $(M=0.6-0.8)$ and two estimates of growth coefficients ( $\mathrm{K}=$ 0.307 and 0.322 ), various combinations of these parameters were used. The southern Brazilian skipjack fishery was commenced recent1y, therefore we chose, as input data, some relatively low values of the rate of exploitation $(\mathrm{F} / \mathrm{Z}=0.4,0.5$ and 0.6$)$ for the largest length class. Since there was little 
Table 1. Estimated number (in thousands) of skipjack tuna caught annually in southeastern Brazilian coast for the period 1980-1983

\begin{tabular}{|c|c|c|c|c|c|}
\hline Length class (cm) Year & 1980 & 1981 & 1982 & 1983 & mean \\
\hline $35-37$ & - & - & - & 7.64 & 1.91 \\
\hline $37-39$ & - & - & - & 26.74 & 6.69 \\
\hline $39-41$ & - & - & - & 15.28 & 3.82 \\
\hline $41-43$ & 1.38 & - & - & 7.64 & 2.26 \\
\hline $43-45$ & 2.76 & 9.17 & 12.22 & 14.42 & 10.81 \\
\hline $45-47$ & 16.56 & 36.68 & 28.51 & 76.39 & 39.54 \\
\hline $47-49$ & 27.61 & 94.77 & 105.91 & 179.52 & 101.95 \\
\hline $49-51$ & 26.23 & 168.14 & 236.27 & 313.20 & 185.96 \\
\hline $51-53$ & 63.50 & 302.65 & 354.41 & 443.07 & 290.91 \\
\hline $53-55$ & 63.50 & 316.88 & 492.91 & 488.90 & 340.05 \\
\hline $55-57$ & 122.86 & 293.48 & 525.50 & 492.72 & 358.64 \\
\hline $57-59$ & 196.02 & 253.73 & 521.43 & 427.79 & 349.74 \\
\hline $59-61$ & 271.95 & 345.45 & 476.62 & 370.50 & 366.13 \\
\hline $61-63$ & 207.07 & 363.79 & 354.41 & 275.01 & 300.07 \\
\hline $63-65$ & 142.18 & 299.59 & 305.52 & 179.52 & 231.70 \\
\hline $65-67$ & 110,43 & 247.62 & 256.64 & 141.32 & 189.00 \\
\hline $67-69$ & 64.88 & 140.62 & 211.83 & 125.05 & 135.85 \\
\hline $69-71$ & 41,41 & 64.20 & 118.13 & 106.95 & 82.67 \\
\hline $71-73$ & 19.33 & 39.74 & 48.88 & 61.11 & 42.27 \\
\hline $73-75$ & 4.16 & 30.57 & 16.29 & 26.74 & 19.44 \\
\hline $75-17$ & - & 33.63 & 8.15 & 15.28 & 14.27 \\
\hline $77-79$ & $=$ & 12.23 & - & 11.46 & 5.92 \\
\hline $79=81$ & - & 3.06 & - & 7.64 & 2.68 \\
\hline $81-83$ & 1.38 & - & - & - & 0.35 \\
\hline Total & 1383.19 & 3054.00 & 4073.63 & 3819.55 & 3082.63 \\
\hline
\end{tabular}

difference between results obtained assuming different exploitation rates, only the results obtained from the lowest exploitation rate, i.e. $\mathrm{F} / \mathrm{Z}=$ 0.4 , are given here. For each combination of the values of $M$ and $K$, we calculated the following information:

1) values of the exploitation rate for each length class,

2) estimates of annual recruitment of fish attaining $43 \mathrm{~cm} \mathrm{FL}$,

3) biomass of skipjack stock in the area.

For application of the length cohort analysis and virtual population analysis, the Burrough B-6900 computer in the computer center at the University of São Paulo was used.

\section{Results}

\section{Analysis of length frequency}

Figure 3 shows monthly length frequency distributions of skipjack tuna observed in the $\mathrm{R}$ io de Janeiro fish market from 1980 to 1983 . The observed ranges were

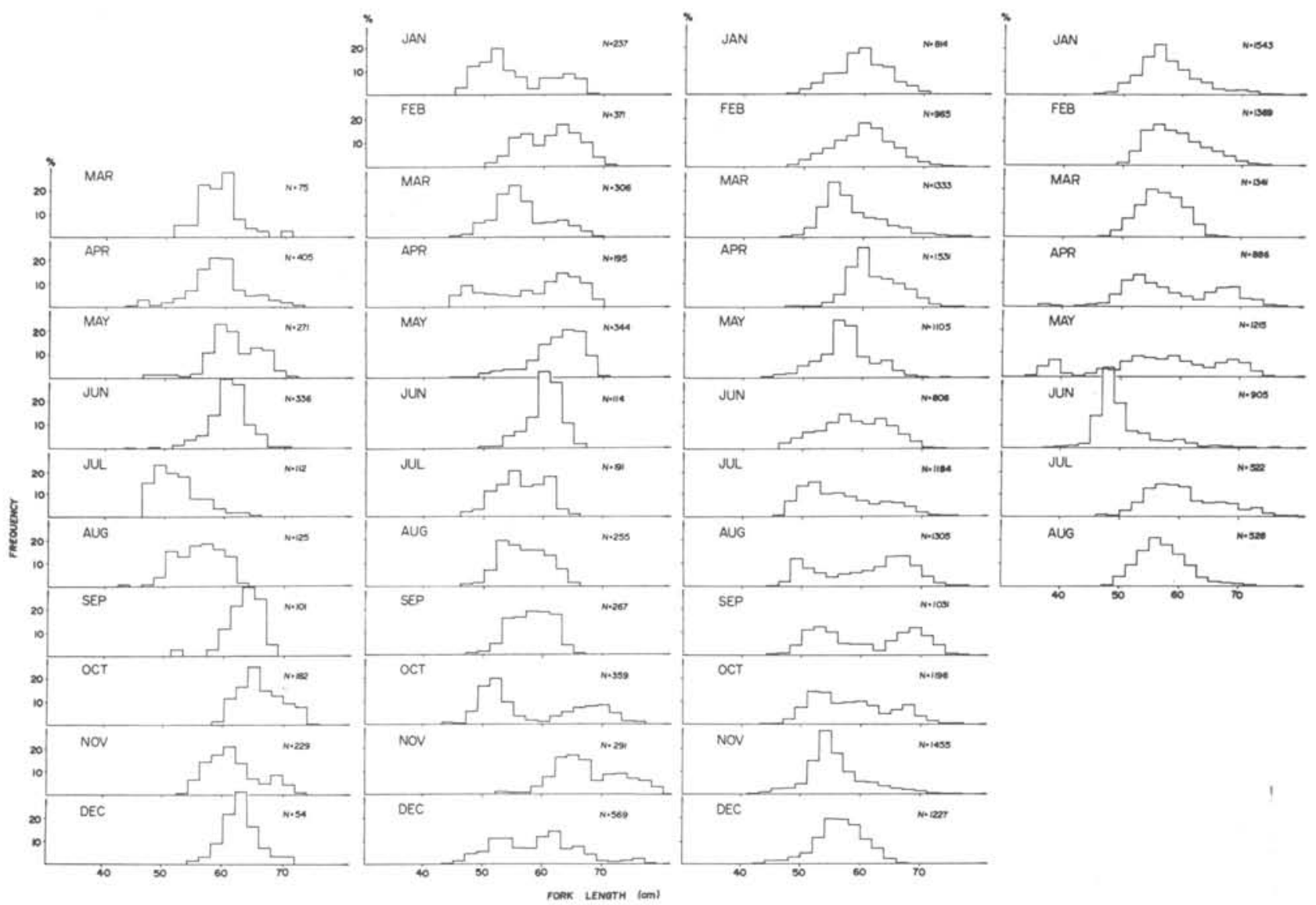

Fig. 3. Monthly size frequency composition of skipjack tuna observed at the Rio de Janeiro fish market, 1980-1983. 
42-82 cm FL in $1980,43-79 \mathrm{~cm} \mathrm{FL} \mathrm{in} 1981$ and 41-78 cm FL in 1982. In 1983 many specimens smaller than $40 \mathrm{~cm}$ FL appeared during the period April-June and the observed range was $34-79 \mathrm{~cm}$ FL. The total number of skipjack tuna measured was 27,650 , ranging from $34 \mathrm{~cm}$ to $82 \mathrm{~cm}$ FL with a mean length of $58.3 \mathrm{~cm} \mathrm{FL}$.

The changes observed in the monthly length frequency distributions failed to show any regularity in progressive growth of each modal group and there was no definite periodicity in the appearance of new modal groups, suggesting constant ingress and egress of different modal groups of $\mathrm{fish}$ in the fishing area. In this figure we can follow the presence of the same modal group for two to three months, after which they were replaced by another modal group.

\section{Estimates of rate of exploitation}

Values of the rates of exploitation $(\mathrm{F} / \mathrm{Z})$ for each length class have been determined by length cohort analysis using the average numbers of fish landed over the four year period (Table 2). We can see that the exploitation rate decreases with an increase in the assumed values of $M / K$.

Table 2. Values of the rate of exploitation $(F / Z)$ using the length frequency distribution of skipjack tuna for the period 19801983

\begin{tabular}{|c|c|c|c|c|c|c|}
\hline \multirow{2}{*}{ 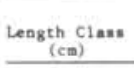 } & \multicolumn{2}{|c|}{$M=0.6$} & \multicolumn{2}{|c|}{$M=0.7$} & \multicolumn{2}{|c|}{$M=0.8$} \\
\hline & $k=0.307$ & $k=0.322$ & $x=0.307$ & $k=0.322$ & $K=0,307$ & $k=0.322$ \\
\hline $35-37$ & 0.002 & 0.002 & 0.001 & 0.002 & 0.001 & 0.001 \\
\hline $37-39$ & 0.008 & 0.008 & 0.005 & 0.006 & 0.003 & 0.004 \\
\hline $39-41$ & 0.004 & 0.005 & 0.003 & 0.003 & 0.002 & 0.002 \\
\hline $41-43$ & 0.003 & 0.003 & 0.002 & 0.002 & $0.00 t$ & 0.002 \\
\hline $43-45$ & 0.014 & 0.015 & 0.010 & 0.011 & 0.007 & 0.008 \\
\hline $45-47$ & 0.051 & 0.056 & 0.036 & 0.041 & 0.026 & 0.030 \\
\hline $47-49$ & 0.127 & 0.138 & 0.095 & 0.105 & 0.070 & 0.079 \\
\hline $49-51$ & 0.222 & 0.239 & 0.172 & 0.188 & 0.131 & 0.146 \\
\hline $51-53$ & 0.330 & 0.350 & 0.266 & 0.286 & 0.210 & 0.231 \\
\hline $53-55$ & 0.394 & 0.415 & 0.326 & 0.368 & 0.264 & 0.288 \\
\hline $55-57$ & 0.443 & 0.464 & 0.374 & 0.397 & 0.310 & 0.334 \\
\hline $57-59$ & 0.481 & 0.502 & 0.412 & 0.435 & 0.347 & 0.372 \\
\hline $59-61$ & 0.547 & 0.567 & 0.479 & 0.502 & 0.412 & 0.438 \\
\hline $61-63$ & 0.563 & 0.583 & 0.496 & 0.319 & 0.430 & 0.456 \\
\hline $63-65$ & 0.573 & 0.592 & 0.507 & 0.529 & 0.442 & 0.468 \\
\hline $65-67$ & 0.608 & 0.626 & 0.544 & 0.565 & 0.479 & 0.504 \\
\hline $67-69$ & 0.629 & 0.646 & 0.565 & 0.587 & 0.501 & 0.526 \\
\hline $69-71$ & 0.626 & 0.644 & 0.562 & 0.583 & 0.497 & 0.522 \\
\hline $71-73$ & 0.390 & 0.609 & 0.526 & 0.546 & 0.459 & 0.484 \\
\hline $73-75$ & 0.526 & 0.545 & 0.460 & 0.482 & 0.399 & 0.422 \\
\hline $75-71$ & 0.594 & 0.612 & 0.533 & 0.554 & 0.475 & 0.697 \\
\hline $77-79$ & 0.571 & 0.588 & 0.516 & 0.533 & 0.460 & 0.481 \\
\hline $79-81$ & 0.624 & 0.638 & 0.578 & 0.593 & 0.535 & 0.551 \\
\hline$M / K$ & 1.956 & 1.863 & 2.280 & 2.174 & 2.606 & 2.484 \\
\hline
\end{tabular}

The exploitation rate at each length for an intermediate value of $M(0.7)$ and a growth constant (K) of 0.307 is shown in Figure 4. The estimated $\mathrm{F} / \mathrm{Z}$ values were very low for length classes between 35 and $45 \mathrm{~cm} \mathrm{FL}$, then increased gradually up to 0.4 in the $53-55 \mathrm{~cm}$ FL class. Above this size the values of $F / Z$ ranged between 0.41 and 0.58 . The weighted mean exploitation rates were 0.060 and 0.448 , respectively for 1 ength classes of $35-55 \mathrm{~cm}$ and larger than 55 cm FL.

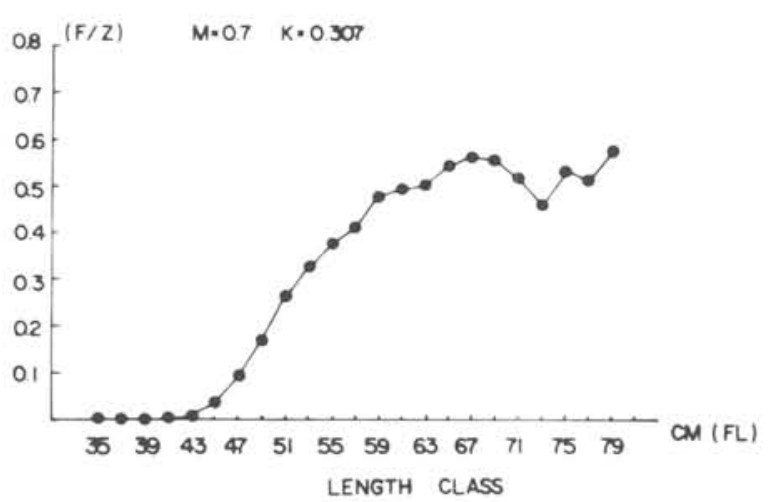

Fig. 4. Change of exploitation rate $(F / Z)$ by length class of the skipjack tuna observed over the period of 19801983.

\section{Annual recruitment}

As pointed out in the original paper of Jones (1981), it is convenient to use the average numbers of fish caught per year over a period of several years to eliminate the possible influence of fluctuations of recruitment. In this case we are assuming that the length composition is representative of a steady state situation and that the numbers caught represent the annual catch per length class.

Estimates of the average numbers (in thousands) of fish attaining each length class annually over a period of four years (1980-1983) is shown in Table 3. The smallest length class common to the four years' observation was $43 \mathrm{~cm}$ FL; thus we used this value as the size of first recruitment in this region. The estimate of the average number attaining a length class of $43 \mathrm{~cm}$ FL over the four year period was $11.0 \times 10^{6} \mathrm{fish}$ for assumed values of $M=0.7$ and $K=0.307$. 
Table 3. Estimate of average numbers (in thousands) of fish attaining each length class by length cohort analysis, using the average numbers of fish caught annually for the period $1980-1983$

\begin{tabular}{|c|c|c|c|c|c|c|}
\hline $\begin{array}{l}\text { Length Class } \\
\text { (cm) }\end{array}$ & $\begin{array}{c}\text { So. Caught } \\
(1000)\end{array}$ & $\begin{array}{c}\text { No. in Sea } \\
(1000)\end{array}$ & $F / Z$ & $2 \Delta t$ & PAt & $\Delta t$ \\
\hline $35-37$ & 1.9 & 16235.3 & 0.001 & 0.090 & 0.000 & 0.129 \\
\hline $37-39$ & 6.7 & 14836.8 & 0.005 & 0.094 & 0.000 & 0.134 \\
\hline $39-41$ & 3.8 & 13504.1 & 0.003 & 0.098 & 0,000 & 0.140 \\
\hline $41-43$ & 2.3 & 12244.0 & 0.002 & 0.102 & 0.000 & 0.146 \\
\hline $43-45$ & 10.8 & 11054.2 & 0.010 & 0.108 & 0.001 & 0.153 \\
\hline $45-47$ & 39.5 & 9924.1 & 0.036 & 0.116 & 0.004 & 0.160 \\
\hline $47-49$ & 101.9 & 8834.7 & 0.095 & 0.130 & 0.012 & 0.168 \\
\hline $49-51$ & 185.9 & 7756.4 & 0.172 & 0.150 & 0.026 & 0.178 \\
\hline $51=33$ & 290.9 & 6675.2 & 0.266 & 0.179 & 0.048 & 0.188 \\
\hline $53-35$ & 340.0 & 5580.6 & 0.326 & 0.207 & 0.067 & 0.199 \\
\hline $55-57$ & 358,6 & 4536.9 & 0.374 & 0.238 & 0.089 & 0.213 \\
\hline $57-59$ & 349.7 & 3577.6 & 0.412 & 0.271 & 0.112 & 0.227 \\
\hline $59-61$ & 366.1 & 2728.8 & 0.479 & 0.329 & 0.157 & 0.245 \\
\hline $61-63$ & 300.1 & 1964.1 & 0.496 & 0.368 & 0.183 & 0.265 \\
\hline $63-65$ & 232.0 & 1359.2 & 0.507 & 0.410 & 0.208 & 0.289 \\
\hline $65-67$ & 189.0 & 901.9 & 0.544 & 0.487 & 0.265 & 0.318 \\
\hline $67-69$ & 135.8 & 554.2 & 0.565 & 0.368 & 0.321 & 0.353 \\
\hline $69-71$ & 82.7 & 313.9 & 0.562 & 0.633 & 0.355 & 0.396 \\
\hline $71-73$ & 42.3 & 166.7 & 0.524 & 0.662 & 0.347 & 0.450 \\
\hline $73-75$ & 19.4 & 86.0 & 0.460 & 0.675 & 0.311 & 0.521 \\
\hline $75-77$ & 14.3 & 43.8 & 0.533 & 0.944 & 0.504 & 0.629 \\
\hline $77-79$ & 5.9 & 17.0 & 0.514 & 1.128 & 0.580 & 0.784 \\
\hline $79-81$ & 2.7 & 5.5 & 0.578 & 1.841 & 1.064 & 1.110 \\
\hline $81+$ & 0.4 & 0.9 & & & & \\
\hline
\end{tabular}

Sote: $\quad M=0.70, \quad K=0.307, \quad L_{\infty}=86.7 \mathrm{~cm} F \mathrm{rL}, \quad F / Z($ for $81+c=c l a s s)=0.4$

The effect of changes in fishing effort

According to the method proposed by Jones (1974), it is possible to determine the effects on yield per recruit of changes in fishing effort, using the values of Fdt obtained in the length cohort analysis. For this we can assume at first approximation that a change in fishing effort would change the values of Fdt at all lengths by the same proportion.

Using the average numbers of fish caught at each length class over a four year period, the expected increment in yield by increasing fishing effort was determined. For $30 \%$ and $50 \%$ increase of fishing efforts, expected yield increments were $8 \%$ and $12 \%$, respectively.

\section{Virtual population analys is}

Because we have no information on the age composition of skipjack tuna caught in Brazilian waters, we tentatively used the age-length key determined by the ageing method of dorsal fin section for skipjack tuna in the eastern Atlantic (Chur et al., 1983) and obtained a rough estimate of the number of skipjack tuna caught at each age group. The average lengths for one to five years-old fish were 29.2, 42.9, 55.5, 65.1 and $69.1 \mathrm{~cm}$ FL, respectively. Table 4 shows estimates of number of skipjack tuna caught per year and agegroup during 1980-1983.

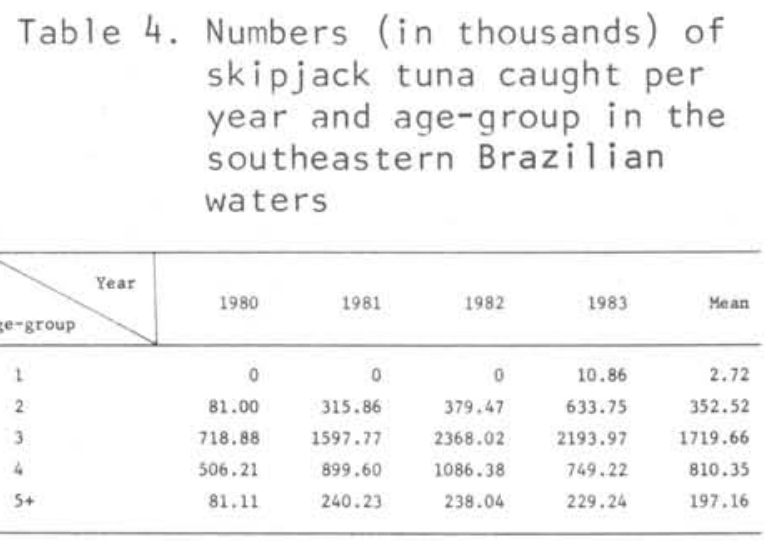

Since there is no evidence of major differences in recruitment for the period 1980-1982, the mean numbers of skipjack tuna were used for virtual population analysis. At the same time, for comparative purpose we used the cohort data of the 1979-year-class of which the numbers of fish caught from second to five-plus year-olds are known, i.e. $81.00,1597.77,1086.38$ and 229.24 thousands fish, respectively

To apply a virtual population analysis, we need, as input data, a fishing mortality coefficient of the last age-group $\left(\mathrm{F}_{\lambda}\right)$. In this paper, we used arbitrarily selected $F_{\lambda}$ values ranging from 0.5 to 0.9 for calculation. Since there is no significant difference between the results obtained from different $F_{\lambda}$-values, only those obtained from $F_{\lambda}=0.5$ are presented.

Table 5 shows the average numbers of skipjack tuna present at the beginning of the year for each age-group obtained from virtual population analysis. The number in the fishing area was estimated to be between 38 and 66 million fish depending on the natural mortality coefficient assumed. Using the lengthweight relationship and the mean length of each age-group presented above, we can calculate the mean biomass of skipjack tuna in this area. The estimated biomass including all agegroups is shown in Table 6 . Since the availability of the first agegroup is very low in this area, we 
Table 5. Stock size estimates (in thousands) at the start of each year for different natural mortality coefficients, using the average numbers of fish caught during 1980-1983 period

\begin{tabular}{lrrr}
\hline \multirow{2}{*}{ Age-group } & \multicolumn{3}{l}{ Natural Mortality Coefficient $(M)$} \\
& \multicolumn{1}{l}{0.6} & 0.7 & \multicolumn{1}{l}{0.8} \\
\hline 1 & 19352.7 & 26798.2 & 38367.4 \\
2 & 10647.4 & 13426.1 & 17139.0 \\
3 & 5532.3 & 6392.3 & 7465.6 \\
4 & 1826.6 & 2031.9 & 2265.2 \\
$5+$ & 433.6 & 473.3 & 474.8 \\
\hline $2-5+$ & 18440.1 & 22323.6 & 27382.5 \\
Total & 37792.8 & 49121.8 & 65749.9 \\
\hline
\end{tabular}

Table 6. Estimates of skipjack tuna biomass for different natural mortality coefficients for the 1980-1983 period (unit: tonnes)

\begin{tabular}{crrr}
\hline Age-group & $M=0.6$ & $M=0.7$ & $M=0.8$ \\
\hline 1 & 18966 & 26262 & 37600 \\
2 & 24489 & 30880 & 39420 \\
3 & 21133 & 24619 & 28519 \\
4 & 10229 & 11379 & 12685 \\
$5+$ & 3301 & 3602 & 3902 \\
\hline $2-5+$ & 59152 & 70280 & 84526 \\
Total & 78118 & 96542 & 122126 \\
\hline
\end{tabular}

can estimate the potencial yield in this region by combining the data for two years-old and olders. The average biomass ranged from 59.2 to 84.5 thousand tonnes for natural mortality coefficients (M) of 0.6-0.8.

Using the XMB-equation of Gulland (1971), the annual potential yield of skipjack tuna was estimated. For different values of $M$, the maximum sustainable yield ranged from 17.7 to 33.8 thousand tonnes.

\section{Discussion}

An analysis of monthly size frequency distribution showed an irregular oscillation of modal size, indicating constant immigration and emigration of different modal groups in the fishing area. Total landings during second semester always decrease to a lower level, which suggests a seasonal change of availability of the stock. It is probable that this change of availa- bility may be associated not only with a change of habitat of skipjack tuna in the fishing area, but also indicates that other areas of major occurrence of skipjack tuna might exist which our fishing boats fail to cover.

The basic parameters required to apply a length cohort analysis are the natural mortality coefficient $(M)$ and growth parameters $\left(K \& L_{\infty}\right)$. The first attempts at age determination of skipjack tuna were presented by Aikawa (1937) and Aikawa \& Kato (1938), based on the growth marks observed on vertebral centra and they obtained an age-length key. Later many researchers have tried to determine the age of skipjack tuna by following the monthly length frequency composition or by reading growth marks on vertebrae (Brock, 1954; Schaefer, 1960; Yokota et al., 1961; Kawasaki, 1965; etc), but attempts to determine absolute age have been inconsistent and there remain large difference between the results obtained by different authors, including Aikawa's.

Recent1y in examining the various hard parts of skipjack, Batts (1972) showed clear growth marks on sections of the first dorsal spine and determined the age-length relationship of skipjack tuna in North Carolina waters.

Using tagging data several estimates of annual growth increments have been presented (Josse et al., 1979; Cayre, 1979; Wild \& Foreman, 1980; Bard \& Antoine, 1983). A series of these recent studies allows us to draw fairly good conclusion about the growth of skipjack tuna. In this paper, we have used growth parameters based on growth ring determination from dorsal spines carried out by Chur et al. (1983).

While skipjack tuna of just over $100 \mathrm{~cm}$ have been caught by the long-1ine fishery, they are an anomaly inasmuch as this size exceeds the limit deemed possible on the basis of physiological calculation (Kitchell et al., 1978; Bardach, 1983). The largest fish measured in the area studied was $82 \mathrm{~cm}$ FL. As shown by Beverton (1963), the body length of the largest fish in commercial catches might be about $95 \%$ of the asymptotic length during early exploitation of the stock. Therefore the asymptotic length $\mathrm{L}_{\infty}=86.7 \mathrm{~cm} \mathrm{FL}$ 
used in this paper seems be reasonable for the stock exploited in this area. As previously pointed out a good estimate of the natural mortality coefficient (M) is not available for either the western or eastern Atlantic populations. The range of natural mortality coefficients presented by Fonteneau (1983) was not precise, since he determined them from consideration of the moderate growth rate and the length of the exploitation period ( 5 to 6 years). For example, he considered values larger than 0.8 not to be realistic because they require a growth rate greater than $20 \mathrm{~cm} /$ year. In the same way values less than 0.6 also seem not to be probable, because of the scarcity of big fish, at least in the catches.

Since we have size frequency data from only four years' observations, we could not apply virtual population analysis on each cohort. To overcome this difficulty, assuming a fairly stable recruitment, we applied the average numbers of $\mathrm{fish}$ caught during the four year period. In addition, for comparative purposes, the cohort of 1979 of which the numbers of fish caught after recruit size are known, was used for virtual population analysis and the result is shown in Table 7 . The total numbers of $\mathrm{fish}$ estimated using the 1979-cohort and average numbers over the four years showed reasonable agreement.

Table 7. Virtual population analys is of the 1979-cohort. (Input data: $M=0.7, F_{\lambda}=0.5$ )

\begin{tabular}{|c|c|c|c|c|c|}
\hline Age-group & $\begin{array}{l}\text { Number" } \\
\text { caught }\end{array}$ & $\begin{array}{l}\text { Fishing mortality } \\
\text { coefficient }\end{array}$ & $\begin{array}{l}\text { Total mortality } \\
\text { coefficient }\end{array}$ & $\begin{array}{c}\text { Survival } \\
\text { rate }\end{array}$ & $\begin{array}{c}\text { Total } \\
\text { no. }\end{array}$ \\
\hline 2 & 81.0 & 0.008 & 0.708 & 0.493 & 14812.6 \\
\hline 3 & 1598.0 & 0.354 & 1.054 & 0.349 & 7312.0 \\
\hline 4 & 1086.0 & 0.834 & 1.534 & 0.216 & 2546.8 \\
\hline $5+$ & 229.2 & 0.300 & - & - & 550.1 \\
\hline
\end{tabular}

Based on the estimated biomass of 96.5 thousand tonnes (with $\mathrm{M}=0.7$ ), we determined the maximum sustainable yield to be 33.8 thousand tonnes, but if we consider only those older than two years, the estimated biomass and the MSY will be 70.3 and 24.6 thous and tonnes, respectively. This result suggests that the actual landing of 18 thousand tonnes is close to the MSY. The results of the length cohort analy$s$ is showed that increasing the fishing mortality rate by $30 \%$ and $50 \%$, we obtained an increment in yield of $8 \%$ and $12 \%$, respectively.

The method applied in this paper permits us to make an estimate of the size of the stock that is currently exploited in the present fishing area. In other words we can estimate how large the stock biomass is, which has sustained the annual landing of 18 thousand tonnes, but probably not the total biomass of the area. Therefore, the estimated MSY does not mean the total potential yield, which can be obtained only by direct stock assessment methods.

Introduction of large purse-seiner in this area which occurred in late 1983, does not imply a qualitative change in the fishery. Thus, if they operate in the same fishing area, we can not expect a significant increase in production. Furthermore, the operation of large purse-seiners will introduce hard competition with the Brazilian bait-boats in terms of disposable skipjack biomass.

Because the size of recruit in this fishing area is relatively large $(43 \mathrm{~cm}$ FL), a growth overfishing problem seems to be remote. Furthermore, their opportunistic reproduction behaviour (Cayre \& Farrugio, 1983) which occurs in the vast tropical and subtropical ocean, may serve as a natural protection of spawners from commercial fishing boat. This indicates that if the actual fishing effort in the southeastern Brazilian waters does not reduce the spawning stock size to very low level, an overfishing problem will not occur. Then, our major concern will be if this skipjack stock is exploited by any other country in another part of the Atlantic, for example, in the eastern central Atlantic or in Caribbean sea?

Comparing genetic data of serum esterase and transferrin systems, Fujino et al. (1981) showed that there are four genetically distinct subpopulations, namely western Pacific, central-eastern Pacific, Indian Ocean and Atlantic subpopulations. However, due to insufficient data from Atlantic and Indian Ocean, he suggested a necessity of further efforts on population study of these two areas to examine any 
possibility of subgrouping within each subpopulation identified.

The results of tagging data obtained during the International Skipjack Year Program (1979-1983) of ICCAT showed there is no evidence of trans-Atlantic movement of skipjack tuna, therefore, at the moment we can treat separately the two stocks exploited in the eastern and western Atlantic.

\section{Acknowledgements}

We thank Dr Roger Bailey of the Marine Laboratory, Aberdeen, for revision and critical reading of the manuscript. Dr Rodney Jones of the same laboratory kindly gave some useful suggestions on the paper.

Financial support came from the Financiadora de Estudos e Projetos S.A. (FINEP), for data processing with computer.

The junior author (Y.M.) received the research fellowship of the Conselho Nacional de Desenvolvimento Científico e Tecnológico (CNPq).

\section{References}

AIKAWA, H. 1937. Notes on the shoal of bonito (skipjack, Katsuwonus pelamis) along the Pacific coast of Japan. Bu11. Jap. Soc. scient. Fish., 6(1): 13-21.

\section{\& KATO, M. 1938. Age} determination of fish (preliminary report). Bul1. Jap. Soc. scient. Fish., 7(1):79-88.

ANKENBRANDT, L. 1983. Food habits of bait-caught skipjack tuna from the southwestern Atlantic ocean. Paper presented at the Proc. int. Skipjack Yr Progm. Conf., ICCAT, June 21-25, 1983, Tenerife, Spain.

BARD, F. X. \& ANTOINE, L. 1983. Croissance du 1 istao dans 1 'Atlantique Est. southwestern Atlantic ocean. Paper presented at the Proc. int. Skipjack is Progm. Conf., ICCAT, June 21-25, 1983, Tenerife, Spain.

BARDACH, J. E. 1983. Pacific tuna: biology, economics, and politics of a large fishery resources. In: Proceedings of the Joint Oceanographic Assembly 1982-general symposia. Canadian National Comm./ SCOR, Ottawa, p. 76-94.

BATTS, B. S. 1972. Age and growth of the skipjack tuna, Katsuwonus pelamis (Linnaeus), in North Carolina waters. Chesapeake Sci., 13(4):237-244.

BEVERTON, R. J. H. 1963. Maturation, growth and mortality of clupeid and engraulid stocks in relation to fishing. Rapp. P.-v. Réun. Cons. perm. int. Explor. Mer, 154:44-67.

BROCK, V. E. 1954. Some aspects of the biology of the aku, Katsuwonus pelamis, in the Hawaiian Islands. Pacif. Sci., 8(1):94-104.

CAYRE, P. 1979. Détermination de 1 'age de 1 istao Katsuwonus pelamis L., debarqués à Dakar. Col. Vol. scient. Pap., ICCAT, 8(1):196-200.

\section{\& FARRUGIO, H. 1983.}

Biologie de la reproduction du listao de 1 'océan Atlantique. Paper presented at the Proc. int. Skipjack Yr Progm. Conf., ICCAT, June 21-25, 1983, Tenerife, Spain.

CAYRE, P. \& LALOE, F. 1983.

Relations poids-1ongueur du listao de 1'ócean Atlantique. Paper presented at the Proc. int. Skipjack Yr Progm. Conf., ICCAT, June 21-25, 1983, Tenerife, Spain.

CHUR, V. N.; OVCHINNIKOV, V. V. \& KOROLEVICH, L. I. 1983. Some problems of studying of age and growth of skipjack (Katsuwonus pelamis L.) of the Atlantic ocean. Paper presented at the Proc. int. Skipjack Yr Progm. Conf., ICCAT, June 21-25, 1983, Tenerife, Spain.

FONTENEAU, A. 1983. Etat des stocks de 1'Atlantique par analyse des cohortes, analyse de production par recrue et par le medèle global. Paper presented at the Proc. int. Skipjack Yr Progm. Conf., ICCAT, June 21-25, 1983, Tenerife, Spain.

FUJINO, K.; SASAKI, K. \& OKUMURA, S. 1981. Genetic diversity of skipjack tuna in the Atlantic, Indian, and Pacific Oceans. Bull. Jap. Soc. scient. Fish., 47(2):215-222. 
GOLDBERG, S. R. \& AU, D. W. K. 1983. The spawning schedule of skipjack tuna from southeastern Brazil as determined from histological examination of ovaries, with notes on spawning in the Caribbean. Paper presented at the Proc. int. Skipjack Yr Progm. Conf., ICCAT, June 21-25, 1983, Tenerife, Spain.

GULLAND, J. A. 1965. Estimation of mortality rates. Annex to Artic Fisheries Working Group Reports. ICES CM 1965/Gadoid Fish. Comm. 3. p. 1-9. (mimeo).

1971. The fish resources of the oceans. London, Fishing News (Books), 255 p.

JABLONSKI, S.; BRAILE, A. A.; ROMÃO, C. M. \& TEIXEIRA, M. S. M. 1983. Sexual maturity and sex-ratios of the skipjack tuna Katsuwonus pelamis (Linnaeus), from southeastern Brazil. Col1. Vol. scient. Papers, ICCAT, 20(1):217-233.

JONES, R. 1974. Assessing the long term effects of changes in fishing effort and mesh size from length composition data. ICES, CM 1974/F, 33:1922-1930.

1979. An analysis of a Nephrops stock using length composition data. Rapp. P.-v. Réun. Cons. perm. int. Explor. Mer, 175:259-269.

1981. The use of length composition data in fish stock assessments (with notes on VPA and cohort analysis). FAO Fish. Circ., 734:1-60.

JOSSE, E.; LE GUEN, J. C. \& KEARNEY, R. F. 1979. Croissance des bonites à ventre rayē. Commission du Pacifique sud Noumea, Nouvelle-Calédonie, Doc. occas., 11:1-33.

KAWASAKI, T. 1965. Ecology and dynamics of the skipjack population (I), (II). Nihon suisan shigen hogo kyokai, suisan kenkyu sosho (Study ser. Jap. Fish. Resour. Conserv. Ass.) (in Japanese).

KITCHELL, J. F. ; NEILL, W. H.; DIZON, A. E. \& MAGNUSON, J. J. 1978.

Bioenergetic spectra of skipjack and yellowfin tunas. In: Sharp, G. D. \& Dizon, A. ed. The physiological ecology of tunas. New York, Academic Press, p. 357-368.

MATSUURA, Y. 1982. Distribution and abundance of skipjack (Katsuwonus pelamis) larvae in eastern Brazilian waters. Bolm Inst. oceanogr., S Paulo, 31 (2):5-7.

1983a. Development of a new Brazilian skipjack fishery in the Rio de Janeiro region. Bul1. Jap. Soc. Fish. Oceanogr., 44:151-154.

19836. Distribution and abundance of skipjack larvae in the western central Atlantic. Paper presented at the Proc. int. Skipjack Yr Progm. Conf., ICCAT, June 21-25, 1983, Tenerife, Spain.

SCHAEFER, M. B. 1960. Report on the investigations of the Inter-American Tropical Tuna Commission for the year 1959. Rep. inter-Am. trop. Tuna Commn, 1959:39-156.

WILD, A. \& FOREMAN, T. J. 1980. The ralationship between otolith increments and time for yellowfin and skipjack tuna marked with Tetracycline. Bul1., inter-Am. trop. tuna Commn, 17(7):509-521.

YOKOTA, T.; TORIYAMA, M, ; KANAI, F. \& NOMURA, S. 1961. Studies on the feeding habit of fishes. Rep. Nankai reg. Fish. Res. Lab., 14:234 p.

ZAVALA-CAMIN, L. A. 1982. Informe sobre la presencia de bonito-1istado (Katsuwonus pelamis) en el contenido estomacal de predadores capturados con palangre en el sudeste y sur del Brasil. Co11. Vo1. Sci. Pap., ICCAT, 17(1): 209-210.

1983. Areas de crescimiento de 1 istado obtenidas por medio de datos historicos de examenes de contenido estomacal de predadores. Paper presented at the Proc, int. Skipjack Yr Progm. Conf., ICCAT, June 21-25, 1983, Tenerife, Spain.

(Received 22-May-84; accepted 14-Dec-84) 